\title{
DEVELOPMENT OF AN EDUCATIONAL VIDEO FOR THE PROMOTION OF EYE HEALTH IN SCHOOL CHILDREN
}

\author{
Jânio Cavalcanti Rodrigues Junior' ${ }^{1}$ Cristiana Brasil de Almeida Rebouças², Régia Christina Moura Barbosa \\ Castro ${ }^{3}$, Paula Marciana Pinheiro de Oliveira ${ }^{4}$, Paulo César de Almeida ${ }^{5}$, Lorita Marlena Freitag Pagliuca ${ }^{6}$
}

\footnotetext{
${ }^{1}$ M.Sc. in Nursing. Professor, Centro Universitário do Vale do Ipojuca. Caruaru, Pernambuco, Brasil. E-mail: janiojunior_pb@hotmail.com 2 Ph.D. in Nursing. Professor, Department of Nursing, Universidade Federal do Ceará (UFC). Fortaleza, Ceará, Brazil. E-mail: cristianareboucas@yahoo.com.br

${ }^{3}$ Ph.D. in Nursing. Professor, Department of Nursing, UFC. Fortaleza, Ceará, Brazil. E-mail: regiabarbosa@hotmail.com

${ }^{4}$ Ph.D. in Nursing. Professor, Universidade da Integração Internacional da Lusofonia Afro-Brasileira. Fortaleza, Ceará, Brazil. E-mail: paulamarciana@yahoo.com.br

${ }^{5}$ Ph.D. in Public Health. Professor, Department of Nursing, Universidade Estadual do Ceará. Fortaleza, Ceará, Brazil. E-mail: pc2015almeida@gmail.com

${ }^{6}$ Ph.D. in Nursing. Professor, Department of Nursing, UFC. Fortaleza, Ceará, Brazil. E-mail: pagliuca@ufc.br
}

\begin{abstract}
Objetive: to build an educational video for early detection of trouble seeing in schoolers.

Method: technology development study in three stages: pre-production, production and post-production in the period from March to December 2014. The recordings were made in a public school in Fortaleza (Brazil) and Health Communication Laboratory in the Universidade Federal do Ceará in the Department of Nursing.

Results: about the evaluation of content, the script was considered valid by all experts. Four (44.4\%) approved the script of the video and five $(55.5 \%)$ approved with modifications. For technical experts, three $(60 \%)$ considered it approved with modifications, while two (40\%) judged it as approved (IVC $\geq 0,8)$. In post-production, it was suggested changes in length, audio and esthetics. The video ended with 16 minutes and 14 seconds.

CONCLUSION: it is believed that the educational video together to health professionals interventions contribute to the public understanding of the subject, resulting in early diagnosis of trouble seeing and resolving eye problems.

DESCRIPTORS: Visual acuity. School health. Instructional films and videos. Health promotion. Educational technology. Nursing.

\section{CONSTRUÇÃO DE VÍDEO EDUCATIVO PARA A PROMOÇÃO DA SAÚDE OCULAR EM ESCOLARES}

\section{RESUMO}

Objetivo: construir um vídeo educativo para detecção precoce da dificuldade para enxergar em escolares.

Método: estudo de desenvolvimento de tecnologia, elaborado em três etapas: pré-produção, produção e pós-produção, no período de março a dezembro 2014. As gravações foram realizadas em uma escola pública de Fortaleza e no Laboratório de Comunicação em Saúde do Departamento de Enfermagem da Universidade Federal do Ceará

Resultados: acerca da avaliação de conteúdo, o roteiro foi considerado válido por todos os especialistas. Quatro (44,4\%) aprovaram o roteiro do vídeo e cinco (55,5\%) aprovaram com modificações. Quanto aos especialistas técnicos, três (60\%) o consideraram aprovado com modificações, enquanto dois (40\%) julgaram-no como aprovado (IVC $\geq 0,8)$. Na pós-produção, sugeriu-se alterações na extensão, áudio e estética. O vídeo foi finalizado com 16 minutos e 14 segundos.

Conclusão: acredita-se que o vídeo educativo, em conjunto com as intervenções de profissionais de saúde, contribua para o entendimento do público a respeito da temática, implicando no diagnóstico precoce da dificuldade em enxergar e resolução dos problemas oculares.

DESCRITORES: Acuidade visual. Saúde escolar. Filmes e vídeos educativos. Promoção da saúde. Tecnologia educacional. Enfermagem. 


\section{CONSTRUCCIÓN DE VIDEO EDUCACITIVO PARA LA PROMOCIÓN DE LA SALUD DE LOS OJOS EN LOS ESCOLARES}

\section{RESUMEN}

Objetivo: construir un video educativo para la detección temprana de problemas para ver en los escolares.

Método: estudio de desarrollo de la tecnología en tres etapas: la pre-producción, producción y post-producción en el período de marzo a diciembre de 2014. Las grabaciones se realizaron en una escuela pública de Fortaleza (Brazil) y Laboratorio de Comunicación em Salud, Departamento de Enfermería de la Universidade Federal do Ceará.

Resultados: sobre la evaluación del contenido, el guión fue considerada válida por todos los expertos. Cuatro (44,4\%) aprobó el guión del video y cinco $(55,5 \%)$ aprobó con modificaciones. En cuanto a los expertos técnicos, tres $(60 \%)$ consideró que aprobó con modificaciones, mientras que dos (40\%) juzgados como aprobado (IVC $\geq 0,8)$. En post-producción, se sugirió cambios en la longitud, el audio y la estética. El vídeo termina con 16 minutos y 14 segundos.

Conclusion: se cree que el video educativo junto a las intervenciones profesionales de la salud contribuyen a la comprensión pública de la materia, lo que resulta en el diagnóstico precoz de problemas para ver y resolver problemas en los ojos.

DESCRIPTORES: Agudeza visual. Salud escolar. Películas y videos educativos. Promoción de la salud. Tecnología educacional. Enfermería.

\section{INTRODUCTION}

Vision is one of the main senses of human beings, as it exerts fundamental influence on development. Therefore, eye problems are a major challenge with regard to health promotion worldwide. ${ }^{1-2}$ Delayed identification and lack of counseling and referral mean that overall $80 \%$ of visual problems occur due to treatable and preventable causes. ${ }^{3}$

The vision integrity is indispensable for the development of the schoolchild. In this perspective, poor vision promotes significant impact on the quality of life, with the ability to cause occupational, intellectual, economic, social and psychological restrictions. The child with vision problems can be seen as different from the others and can develop feelings of inferiority in relation to other apparently healthy children, aggravating their school performance, social interaction and establishing a degree of insecurity and low self-esteem..$^{1,4}$

Children with vision problems show signs and symptoms suggestive of this limitation, which can be observed through the behavior of the student during their activities in the classroom, as well as through voiced complaints in the household. It is for this reason that teachers, parents and family members have an important and often decisive role in the early diagnosis of the child with vision problems. This group required educational activities to guarantee means of coping with such problems. ${ }^{5}$

Using an audiovisual resource in the form of an educational video, can allow for a more sophisticated teaching-learning relationship, because through it, it is possible to capture the attention of the public, as well as to arouse their curiosity in relation to the topics addressed, since society lives in a culture where visual ability and the ability to process information are constantly exercised. ${ }^{6}$

Due to its versatility and applicability, educational videos have been used by nurses as an effective health promotion strategy. Contemplated in the Brazilian National Health Promotion Policy, this concept indicates diverse actions to preserve and increase the individual and social potential of choosing different healthy life forms. In its scope, it reinforces two paths to be pursued. The first one, through the search for integral care and the second, in the construction of public policies favorable to life, through intersectoral articulation. ${ }^{7}$ Therefore, the educational video will allow the eye health of the schoolchild to be contemplated, joining health and education together. ${ }^{8}$ Producing images and videos, arouses interest and therefore enhances the learning of the viewer. Through the use of educational technology, nurses can disseminate guidelines on the most varied health topics, and in turn helping nursing care. ${ }^{9-11}$ Thus, when using the audiovisual resource, the nurse offers the public a solid knowledge base so that he/she can better understand the information, have the capacity to form a critical opinion on a particular theme, and yearn to transform the environment in which they are in, aiming at a better quality of life and personal satisfaction. ${ }^{9,12}$

Considering the negative repercussion that eyesight problems can cause in the life of the child, this study was carried out as an innovative proposal. Thus, we aimed to construct an educational video to guide and teach parents, families and teachers about the main behaviors expressed by schoolchildren who have vision problems. It is believed that with the use of this educational strategy, nurses will contribute to eye health education and the prevention of more serious visual problems. 


\section{METHOD}

A technological development study, developed in three phases: pre-production, production and post-production of the educational video. ${ }^{13}$ The study period, including the three phases, had a duration of ten months, occurring between March and December 2014.

The pre-production was completed in two stages. In the first stage, the content of the script of the video (first version of the script) was elaborated. For this, the main behaviors that portray school children with eyesight difficulties were investigated in the literature. For the development of the first version of the script, a video producer assisted, due to the technical and specific language, specific to the area of social communication and cinema.

After drafting the content of the video script, the material was submitted for validation. This analysis was composed of nine content specialists, related to the health area and, later, by five technical specialists in the area of social communication and cinema. They were selected according to the degree of specialties, experience with the subject of the study and technique used in videos. This validation step can be defined as the verification of the item relevance proposed by the study material and their representativeness in relation to their objectives. ${ }^{14}$

The script along with the evaluation tool was provided to the specialist. In the evaluation instrument, they were asked to indicate the extent to which they agreed or disagreed with each category, and a Likert scale was composed of four items, attributing the degree of relevance: $\mathrm{N}=$ nonrepresentative; $G R=i$ item needs major revision to be representative; $P R=$ item needs small revision to be representative; And R=representative. At the end of each category, there was room for the specialist to justify his response or to make suggestions. ${ }^{14}$

The analysis of the behavioral adequacy of the items occurred through the Content Validity Index (CVI). The calculation of this index was carried out by dividing the sum of the responses considered adequate (degree of relevance PR and degree of relevance R) by the total number of responses. ${ }^{14}$ Items that obtained concordance indices greater than or equal to $80 \%(0.8) .{ }^{15}$ Those who did not reach a minimum agreement were reviewed or withdrawn.

The aspects evaluated by the content specialists consisted of: concept idea, dramatic construction, rhythm, characters, dramatic potential, dialogues, visual style, public reference, and relevance. The proposed and considered relevant changes were incorporated into the instrument and the material was forwarded to content experts. The submission for the validation of the technical aspects occurred only after the content validation. The technical experts must analyze: iconcept idea, dramatic construction, rhythm, characters, dramatic potential, dialogues, visual style, public reference, functionality, usability and efficiency. Thus, as in the validation of content, the changes proposed and considered pertinent by the technical experts were incorporated into the instrument, establishing the final version of the script.

The production stage of the video consisted of the work of six professionals specialized in the area of Video production, they included: scene director, photographic director, camera operator, lighting/ sound operator, electrical assistant/machinery and set designer. Five professional actors participated in the recording, all registered to a licensed video production company, two non-professional actors, the researcher himself and his advisor, as well as 18 schoolchildren, who were enrolled in the school in the neighborhood where the recordings were made. The inclusion criteria for the selection of students were to be attending the 5 th year of elementary school, want to participate in the recordings on the given day and show commitment in the filming period. The recordings were performed in two days. On the first day, the filming took place in a primary and secondary school located in Rodolfo Teófilo, Fortaleza-CE (Brazil). It was selected because it was close to the Nursing Department and to facilitate the assembly and recording of the scenes as well as the fact of having two classes of the fifth year of elementary school.

In the said school, scenes were recorded in the classroom, in the corridors, in the courtyard and in the teachers' room. The decision to shoot at a school rather than a film studio was based on the need to reproduce credible scenes depicting the reality of public school students, including not only the presence of the school audience but also a concrete physical environment. On the second day, recordings were done at the Health Communication Laboratory (LabCom_Saúde) in the Nursing Department of the Universidade Federal do Ceará (UFC), where the physician's office, the living room of Pedro's house (the protagonist) were represented.

Post-production, the last step for the construction of the video, was the time in which the "raw product" obtained in the previous phases was worked on to reach its final result, the video itself. ${ }^{13}$

The post-production stage was under the responsibility of two specialized professionals, 
the stage director and photographic director who were also part of the educational video recordings. They edited the video through the Adobe Photoshop, Lightrron, Premiere, and Sound Forge Programs. The selection, editing and organization of the scenes, choice and editing of the sound track and insertion of the visual effects, assembly and pairing of the images, overlapping characters, subtitles and figures were performed using these software. The project was approved by the Re- search Ethics Committee of the Federal University of Ceará under Opinion n. 666,360 and CAAE 30213314.2.00005054.

\section{RESULTS}

Tables 1 and 2 show the distribution of agreements among content experts (nine) regarding subcategories of the video script instrument and the CVI according to each category, respectively.

Table 1 - Distribution of agreements among content specialists regarding the subcategories of the educational video script instrument. Fortaleza, CE, Brazil, 2014

\begin{tabular}{|c|c|c|c|}
\hline Categories/subcategories & Yes & No & $\%$ \\
\hline \multicolumn{4}{|l|}{ Concept idea } \\
\hline Relevant thematic content & 9 & - & 100,0 \\
\hline Coherent content with video objective & 8 & 1 & 88,0 \\
\hline Video objective coherent with practice & 8 & 1 & 88,0 \\
\hline Assumptions exposed correctly & 7 & 2 & 77,0 \\
\hline Comprehenable information & 9 & - & 100,0 \\
\hline Sufficient Information & 7 & 2 & 77,0 \\
\hline Appropriate for the use of health professionals & 9 & - & 100,0 \\
\hline Proposes a change in behavior & 9 & - & 100,0 \\
\hline \multicolumn{4}{|l|}{ Dramatic Construction } \\
\hline Starting point has impact & 9 & - & 100,0 \\
\hline Script interest grows & 8 & 1 & 77,0 \\
\hline Nice script presentation & 8 & 1 & 100,0 \\
\hline Scenes reflect stereotype/discrimintion & 7 & 2 & 33,0 \\
\hline \multicolumn{4}{|l|}{ Rhythm } \\
\hline Scenes motive the next scenes & 8 & 1 & 88,0 \\
\hline Tiring rythym & 1 & 8 & 88,0 \\
\hline \multicolumn{4}{|l|}{ Characters } \\
\hline Character empathy & 8 & 1 & 88,0 \\
\hline Sufficient ent characters and situations & 8 & 1 & 88,0 \\
\hline \multicolumn{4}{|l|}{ Drama Potential } \\
\hline Has emotion & 8 & 1 & 88,0 \\
\hline Has surprises & 8 & 1 & 88,0 \\
\hline \multicolumn{4}{|l|}{ Dialogue } \\
\hline Dialogue is natural & 7 & 2 & 77,0 \\
\hline
\end{tabular}




\begin{tabular}{|c|c|c|c|}
\hline Categories/subcategories & Yes & No & $\%$ \\
\hline Characters use appropriate language & 6 & 3 & 66,0 \\
\hline Has an ending & 9 & - & 100,0 \\
\hline Relevant ending & 7 & 2 & 77,0 \\
\hline \multicolumn{4}{|l|}{ Visual style } \\
\hline Comprehendable symbols & 9 & - & 100,0 \\
\hline Scenes reflect important aspects & 9 & - & 100,0 \\
\hline \multicolumn{4}{|l|}{ Referenced Audience } \\
\hline The content is related to the audience & 9 & - & 100,0 \\
\hline Identification of the target audience with the problem & 9 & - & 100,0 \\
\hline Compatible language with the audience knowledge & 9 & - & 100,0 \\
\hline \multicolumn{4}{|l|}{ Relevancy } \\
\hline Script illustrates important thematic aspects & 8 & 1 & 88,0 \\
\hline Relevant scenes for the target audience & 8 & 1 & 88,0 \\
\hline Script creates an abstract or revision & 8 & 1 & 88,0 \\
\hline
\end{tabular}

One can observe the unanimous agreement of the nine content specialists regarding the categories/subcategories identified in table 1 . Regarding the general evaluation, four $(44.4 \%)$ content experts approved the video script and five $(55.5 \%)$ approved the video script with the need for modifications.

Among the modifications suggested by the content specialists, there was a substitution of technical terms for colloquial terms and play definitions, an increase in behaviors that portray vision difficulties, a decrease in the number of signs and symptoms exhibited by only one character, and the insertion of a scene that emphasized the improvement of the child after the optical correction. With this, the content of the script of the video was considered valid by all the specialists, obtaining an agreement index greater/equal to $0.8(80 \%)$.

Table 2 - Content validity index among content specialists according to each category. Fortaleza, CE, Brazil, 2014

\begin{tabular}{lccc}
\hline \multirow{2}{*}{ Categories } & \multicolumn{2}{c}{ Content } & \multirow{2}{*}{ CVI } \\
\cline { 2 - 3 } & Representative & Non representative & 0,88 \\
Concept idea & 8 & 1 & 1,00 \\
Dramatic construction & 9 & - & 1.00 \\
Rythm & 9 & - & 0,88 \\
Characters & 8 & 1 & 0,88 \\
Dramatic potencial & 8 & 1 & 0,88 \\
Dialogues & 8 & 1 & 1,00 \\
Visual style & 9 & - & 1.00 \\
Target audience & 9 & - & 0,88 \\
Relevancies & 8 & 1 & \\
\hline
\end{tabular}

The technical experts five evaluated the categories, concept idea, dramatic construction, rhythm, characters, dramatic potential, dialogues, visual style, target audience and relevancy, adding the cat- 
egories functionality, usability and efficiency. The on the subcategories of the video script instrument

distribution of agreement among technical experts is presented in table 3.

Table 3 - Agreement between the technical specialists of the educational video script. Fortaleza, CE, Brazil, 2014

\begin{tabular}{|c|c|c|c|}
\hline Categories/subcategories & Yes & No & $\%$ \\
\hline \multicolumn{4}{|l|}{ Concept Idea } \\
\hline Thematic content appropriate for objective & 5 & - & 100,0 \\
\hline Assistance to learning & 5 & - & 100,0 \\
\hline Accessible & 5 & - & 100,0 \\
\hline Script is useful & 5 & - & 100,0 \\
\hline Attractive script & 5 & - & 100,0 \\
\hline \multicolumn{4}{|l|}{ Dramatic construction } \\
\hline Impactful sstarting point & 5 & - & 100,0 \\
\hline Interest in script grows & 5 & - & 100,0 \\
\hline Sufficient number and duration of scenes & 4 & 1 & 80,0 \\
\hline Pleasant script presentation & 5 & - & 100,0 \\
\hline \multicolumn{4}{|l|}{ Rythm } \\
\hline There is growing attraction with a dramatic curve & 5 & - & 100,0 \\
\hline Environment dynamism & 4 & 1 & 80,0 \\
\hline Ways of presenting the appropriate scene & 5 & - & 100,0 \\
\hline \multicolumn{4}{|l|}{ Characters } \\
\hline Original character profile & 5 & - & 100,0 \\
\hline Characters with consistent values & 4 & 1 & 80,0 \\
\hline \multicolumn{4}{|l|}{ Dramatic potential } \\
\hline The existence of expectation & 5 & - & 100,0 \\
\hline \multicolumn{4}{|l|}{ Dialogues } \\
\hline Each intervention motivates the next & 5 & - & 100,0 \\
\hline There is action acceleration until the climax & 5 & - & 100,0 \\
\hline \multicolumn{4}{|l|}{ Visual style } \\
\hline Comprehensive symbols & 5 & - & 100,0 \\
\hline Scenes reflect important aspects & 5 & - & 100,0 \\
\hline \multicolumn{4}{|l|}{ Target audience } \\
\hline The content is related to the audience & 5 & - & 100,0 \\
\hline \multicolumn{4}{|l|}{ Functionality } \\
\hline $\begin{array}{l}\text { Video proposes to empower teachers, parents and family members } \\
\text { about behaviors which indicate vision problems in school children }\end{array}$ & 5 & - & 100,0 \\
\hline Video gave positive results & 5 & - & 100,0 \\
\hline \multicolumn{4}{|l|}{ Usability } \\
\hline The video is easy to use in public health clinics and schools & 5 & - & 100,0 \\
\hline The concept is easy to learn and apply & 5 & - & 100,0 \\
\hline Can be used by a health professional & 5 & - & 100,0 \\
\hline
\end{tabular}




\begin{tabular}{llrr}
\hline Categories/subcategories & Yes & No & $\%$ \\
\hline Efficiency & & & \\
Proposed timing & 4 & 1 & 80,0 \\
Number of scenes are coherent to proposed timing & 5 & - & 100,0 \\
Characterization of the characters meets the proposed goals & 5 & - & 100,0 \\
Efficient and comprehendible communication between characters & 5 & - & 100,0 \\
\hline
\end{tabular}

One can observe agreement among the five technical experts regarding the categories: concept idea, dramatic potential, dialogues, visual style, target audience, functionality and usability. There was no unanimity in the categories/subcategories: dramatic construction (sufficient number and duration of scenes), rhythm (environment dynamism), characters (characters with consistent words), and efficiency (adequate time proposed).

In the overall evaluation, three $(60 \%)$ technical experts approved the video script but ap- proved it with the need for modifications, while two $(40 \%)$ judged it as approved, obtaining an agreement index of $1.00(100 \%)$ in all categories, according to table 4 . The technical experts suggested the reduction of the number of scenes due to the incompatibility with the proposed time for the video; dynamism in recording environments; maintaining an average for the times of the scenes, allowing to make the script more interesting and accessible, as well as reducing the dialogues to give more intensity to the dramatic action.

Table 4 - Content Validity Index among technical experts according to each category. Fortaleza, CE, Brazil, 2014

\begin{tabular}{lccc}
\hline \multirow{2}{*}{ Categories } & \multicolumn{2}{c}{ Content } & \multirow{2}{*}{ CVI } \\
\cline { 2 - 3 } & Representative & Non representative & 1,00 \\
Concept idea & 5 & - & 1,00 \\
Dramatic construction & 5 & - & 1,00 \\
Rythm & 5 & - & 1,00 \\
Characters & 5 & - & 1,00 \\
Dramatic potential & 5 & - & 1,00 \\
Dialogue & 5 & - & 1,00 \\
Visual style & 5 & - & 1,00 \\
Target audience & 5 & - & 1,00 \\
Functionality & 5 & - & 1,00 \\
Usability & 5 & - & 1,00 \\
Efficiency & 5 & & \\
\hline
\end{tabular}

In post-production, changes in the extension, audio and aesthetic factors of the video were suggested, which included: increase in the font size of the characters, replacement of video photos with images/photos compatible with the regional reality and video clips, keywords overlapping concomitantly with the appearance of the images in the voice off, and homogenization of the audio in the voices of the characters in scene and in off.

The total video duration was 16 minutes and 14 seconds, including the credits, staying within the anticipated time for educational videos so that the audience can maintain their attention to the content.

\section{DISCUSSION}

During the first stage named pre-production, the thematic content was considered as relevant/ current, with comprehensible information and contain suitable material for the use of health professionals and which could propose behavior change.

A study about the promotion of safe breastfeeding between seropositive mothers and their children legitimizes the issue of educational video as a potential resource in the teaching-learning process in the practice of health professionals. In this study, the audiovisual resource was effective 
in the interaction between mother and baby who experienced the reality of HIV/AIDS infection. ${ }^{16}$

The advent of new emancipatory technologies, such as educational video, has enabled the health professional to innovate ways of exchanging knowledge with the public, as it approaches the content addressed in reality, in addition to arousing interest and promoting better learning. ${ }^{17}$

During the audiovisual transmission, it is essential that the communication between the characters are consistent with the level of knowledge of the viewers. For this, dialogues with scientific terms and complex phrases used by the characters in the script of the video have been replaced by more common language, with playful definitions to make it easy to understand for the audience. Using playful definitions means making the content more attractive, fun and simplified, thus contributing to the learning and construction of knowledge. ${ }^{18-19}$

Strabismus was added in the script, thus increasing the number of behaviors of difficulty in seeing exposed in the educational video. It's a disease that corresponds to loss of parallelism between the eyes in a convergent, divergent or vertical way, can cause amblyopia of the deviated eye, affecting up to $5 \%$ of the world population. ${ }^{20}$ Since eye alignment is a necessary condition for the normal development of vision and that such an aggravation needs to be detected and treated as early as possible.

In the context of nursing care in ocular health, one specialist stated that activities to promote visual health are not part the nurse's practice. However, the Ministry of Health affirms that it is the responsibility of the Family Health Strategy, together with the School Health Program to incorporate into its routine actions to promote and prevent eye health problems in school. Essential nursing actions such as verifying visual acuity through the Snellen test in conjunction with preventive and health promotion activities for elementary, middle school, and youth and adult education students are important. ${ }^{21}$

Health Promotion is a broad concept which has been studied over the years, is related to the improvement of the quality of life of the population, community empowerment, and the maintenance of health-friendly environments..$^{22}$ In this regard, promotion strategies and actions should involve different environments through public policies and conditions conducive to the development of health. Therefore, it is necessary to strengthen the skills of the people involved, in this case, the school, the teachers and the family. As for character choice, the figure of the teacher stands out as being the profes- sional who most frequently notices the visual deficiency in school children, and who are considered a central element for the identification of behaviors that imply visual disturbances in school children. ${ }^{5}$ According to research, $62.7 \%$ of the educators, among them teachers and pedagogical coordinators, stated that they have children as students with some visual impairment or poor vision among their students however, they reported not feeling prepared to deal with such children. ${ }^{23}$

Scientific literature corroborates the level of unpreparedness of teachers regarding eye health, and in this literature, the teachers acknowledge that they have little or no knowledge to help students with vision problems besides stating that they have not received guidance or training on the subject in recent years ${ }^{5,23-24}$ From this perspective, the need to implement continuing education programs for teachers in the field of eye health is highlighted, in order to establish early diagnosis, prevention of visual incapacity and blindness in school children. 5,24

In regards to signs and symptoms related to visual illness, the video included a significant number of behaviors demonstrated by children with vision problems. Thus, we sought information from previous research through literature review. In this literature review, 30 behaviors associated with difficulty in seeing were identified. In the first version of the script, it was 19 behaviors were contemplated which were suggestive of visual alteration. In the final version, the specialist's evaluation, 11 signs and symptoms were presented, paying close consideration to the principal ones.

The literature highlights the most common signs and symptoms: visual problems causes burdens in learning and socialization, low school performance, exam failing, difficulty in reading and writing, sensitivity to light, headaches, frowning, tearing, holding objects extremely close to the face, hanging head to one side or covering one eye during reading, blinking excessively, frequently rubbing eyes, reports of blurred vision, post-reading fatigue, large and crooked handwriting, annoyance when watching television and difficulty in concentrating.

During the dramatizations carried out in the classroom, while the teacher taught the lesson, some students talked and disturbed her. Consequently, the teacher warned the students about their inappropriate behavior, using polite and cordial terms, thus making the plot lighter. Within the classroom, the teacher is idealized as a reference and, obviously, their attitudes reflect directly on the behavior of his students. 
In the midst of this fact, there is a need for the teacher to establish an ethical conduct during their pedagogical practices. ${ }^{25}$ From this perspective, the judges' evaluation was positive, highlighting the importance of the visual health theme.

Educational actions become the basis for the promotion of eye health. Health education aims to enable the public to improve living conditions, including behaviors directed at the early diagnosis / intervention of visual problems of school children. Thus, the practices of health education actions in schools contribute to the integral formation of students in coping with vulnerabilities as well as in the formation of citizens. ${ }^{26}$

Authors suggest that programs aimed at prevention and promotion of ocular health need to be developed in a continuous way, with the participative collaboration of the whole group that surrounds the child. Parents, teachers, health professionals, and the community at large should be included to form a preventive and health promotion culture. ${ }^{26}$

It is believed that educational materials such as video can spark people's interest. When well elaborated through idea and dramatic construction, it becomes attractive and effective to the goal that is proposed. It is known that in an audiovisual presentation audience attention is highlighted. ${ }^{27}$ Attention time is the period of time which the audiovisual resource has in order to capture the attention of the public, thus the video must be attractive to be able to keep the attention of the viewer. When working with longer scenes, the dynamism and attractiveness of the action must be amplified, otherwise the action is not sustained and the viewer loses interest. ${ }^{27}$

A study involving a new pedagogical approach for teaching of medical students using educational videos for the teaching of semiology skills and medical procedures, revealed that the content became more attractive, students became more motivated and had greater self-confidence to perform procedures after watching the audiovisual display. ${ }^{28}$

From the various aspects to be approached in a video, the rhythm, i.e. the dynamism between environments, scenarios and characters, is highlighted as an important requirement for the good understanding of the group. It should be noted the importance of selecting the environment where the dramaturgy will be performed, where lighting, space proportions, angulation and color, environment and decoration, costumes and props are important elements for the composition of an audiovisual scene. ${ }^{27}$

In the audiovisual language there is a combination of images, sounds and speech. The musical display during a video is able to express and communicate feelings, emotions and thoughts, favoring the construction of reasoning and learning. In this perspective, choosing appropriate audio is of fundamental importance in cinematographic construction and development. ${ }^{19,27}$

Its technical functionality corroborates the essentials for creating an educational video. The video has a double essence, besides being a means of communication, it is also teaching. The use of the audiovisual resource in an appropriate way, with interactivity and emotion, maximizes learning and knowledge. ${ }^{19}$

An educational study based on technology development corroborates the use of educational video as an educational tool. In this study, the construction of a video on the early detection of breast cancer was described, where disease prevention, health promotion and population engagement were stimulated. ${ }^{29}$

In the usability category, all were unanimous in affirming that the video can be easily used by health professionals during their activities, being able to be used both in the school environment and in Public Health Units, and obtaining approval without the need for modifications. Due to its practicality and usability, video has been used in pedagogical practice by health professionals as it arouses the attention and curiosity of the public who watches it. However, the professional who uses video as an educational tool needs to be aware of some aspects before, during and after it is shown.

First of all, he must know which video that will be used, and watch it in advance, selecting and adapting each subject to a specific audience. After, the content should be discussed in order to clear up any doubts that may exist. ${ }^{9,18}$

Educational videos directed to communities where health promotion actions are developed are used to sensitize a social group to modify behaviors in the face of health problems. In addition, it provides immediate behavior change because it is an easily accessible medium; and it facilitates the educational process, resulting in improved quality of health care. ${ }^{30-31}$

One of the limitations of this study was the validation time spent by specialists. Due to the difficulty in finding professionals who met the established criteria, specialists from all over Brazil were selected. The information that was received by e-mail caused the content validation and technique to exceed the anticipated time. It is suggested that those interested in carrying out similar researches 
choose the face-to-face validation method, with the participation of all the specialists together with the researcher and advisor. In this way, there would be a greater exchange of experience among the participants, clarifying the doubts and listening to suggestions that may arise in a timely manner, and thus streamlining the validation process.

\section{CONCLUSION}

Empowering the population to promote visual health is paramount in preventing treatable and preventable visual changes from developing into permanent visual disturbances. Thus, educational videos become an important resource for teachers, parents and family members in identifying behaviors in schoolchildren associated with visual impairment.

Regarding the overall evaluation of the video, the script was approved by specialists $(\mathrm{CVI} \geq 0.8)$, which $57.1 \%$ suggested that some types of modification were required. Among these modifications, a reduction in the number of scenes, dynamism in recording environments, substitution of technical terms for colloquial terms and playful definitions, expansion of behaviors that portray difficulties in seeing, decrease in the number of signs and symptoms exhibited by only one character, scene insertion that emphasized the child's improvement after optical correction, changes in the extension, audio and aesthetic factors of the video, including: increase font size of characters, replace video photos with compatible images/photos, regional reality and using video clips from the video itself.

It is believed that this educational video is now constructed and validated, and incorporated into the interventions and guidance of a qualified health professional, which contribute to the target audience's comprehension regarding the issue of visual health, leading to the early diagnosis and effective resolution for schoolchild with vision problems. In this perspective, the educational video becomes a tool which facilitates the nurses' performance in their educational practices with children, parents, teachers and the community.

\section{REFERENCES}

1. Antonelli JW, Netto AA, Dário CS, Ferré LB, Pereira MCSR. Prevalência de baixa acuidade visual em crianças de escolas públicas e privadas de Tubarão-SC. Rev Bras Pediatr Mod. 2012 Jun; 48(6):229-36.

2. Toit R, Faal HB, Etya'ale D, Wiafe B, Mason I, Graham R, et al. Evidence for integrating eye health into primary health care in Africa: a health systems strengthening approach. BMC Health Services Res [Internet]. 2013 Mar; [cited 2015 Oct 13]; 13:102. Available from: http://www.biomedcentral.com/ content/pdf/1472-6963-13-102.pdf

3. Mahmoud AO, Kuranga AS, Ayanniyi AA, Babata AL, Adido J, Uyanne IA. Appropriateness of ophthalmic cases presenting to a Nigerian tertiary health facility: implications for service delivery in a developing country. Niger J Clin Pract. 2010 Sep; 13(3):280-83.

4. Bravo Filho VTF, Ventura RU, Brandt CT, Sarteschi C, Ventura MC. Impacto do déficit visual na qualidade de vida em idosos usuários do Sistema Único de Saúde vivendo no sertão de Pernambuco. Arq Bras Oftalmol. 2012 Mai-Jun; 75(3):161-5.

5. Cavalcanti Junior J, Rebouças CB, Dantas RA, Pagliuca LM. Teachers' knowledge about signs/symptoms which indicate low visual acuity in students. Rev Enferm UFPE on line [Internet]. 2015 Abr; [cited 2015 Oct 13]; 9(4):7289-94. Available from: http://www. revista.ufpe.br/revistaenfermagem/index.php/ revista/article/view/6478/pdf_7505

6. Ashaver D, Igyuve SM. The use of audio-visual materials in the teaching and learning processes in colleges of education in Benue State-Nigeria. J Res Method Educ. 2013 May-Jun; 1(6):44-55.

7. Ministério da Saúde (BR). Secretaria de Vigilância em Saúde. Secretaria de Atenção à Saúde. Política Nacional de Promoção da Saúde: PNPS: revisão da Portaria MS/GM n 687, de 30 de março de 2006. Brasília (DF): Ministério da Saúde; 2015.

8. Champangnatte DMO, Nunes LC. A inserção das mídias audiovisuais no contexto escolar. Educ Rev. 2011 Dez; 27(3):15-38.

9. Blomberg G, Sherin MG, Renkl A, Glogger I, Seidel T. Understanding video as a tool for teacher education: investigating instructional strategies to promote reflection. Instr Sci [Internet]. 2014 Jun; [cited 2015 Out 13]; 42:443-63. Available from: http://link.springer. com/article/10.1007\%2Fs11251-013-9281-6\#/ page-1

10. Barbosa GOL, Wanderley LD, Rebouças CBA, Oliveira PMP, Pagliuca LMF. Development of assistive technology for the visually impaired: use of the male condom. Rev Esc Enferm USP. 2013 Oct; 47(5):1158-64.

11. Pereira CDFC, Tourinho FSV, Robeiro JLS, Medeiros SB, Santos VEP. Functional health patterns: nursing diagnoses in public school-aged children and adolescents. Texto Contexto Enferm. 2013 Oct-Dec; 22(4):1056-63.

12. Nietsche EA, Lima MGR, Rodrigues MGS, Teixeira JÁ, Oliveira BNB, Motta CA, et al. Tecnologias inovadoras do cuidado em enfermagem. Rev Enferm UFSM. 2012 Jan-Abr; 2(1):182-9.

13. Fleming SE, Reynolds J, Wallace B. Lights... camera... action! A guide for creating a DVD/Video. Nurse Educ. 2009 May-Jun; 34(3):118-21. 
14. Alexandre NMC, Coluci MZO. Validade de conteúdo nos processos de construção e adaptação de instrumentos de medidas. Ciênc Saúde Coletiva. $2011 \mathrm{Jul} ; 16(7): 3061-8$.

15. Lynn MR. Determination and quantification of content validity. Nurs Res. 1986 Nov-Dec; 35(6):382-5.

16. Barbosa RM, Bezerra AK. Validação de um vídeo educativo para promoção do apego entre mãe soropositiva para HIV e seu filho. Rev Bras Enferm. 2011 Mar-Apr; 64(2):328-34.

17. Salvador PTCO, Oliveira RKM, Costa TD, Santos VEP, Tourinho FSV. Tecnologia e inovação para o cuidado em enfermagem. Rev Enferm UERJ. 2012 Jan-Mar; 20(1):111-7.

18. Santos PR, Kloss S. A criança e a mídia: a importância do uso do vídeo em escolas de Joaçaba/SC. Unoesc Ciência-ACHS. 2011 Mar; 1(2):103-10.

19. Salina L, Ruffinengo C, Garrino L, Massariello $\mathrm{P}$, Charrier L, Martin B, et al. Effectiveness of an educational video as an instrument to refresh and reinforce the learning of a nursing technique: a randomized controlled trial. Perspect Med Educ. 2012 May; 1(2):67-75.

20. Moitinho LMN, Marback EF, Maia Junior OO, Marback RL. Inflamação esclerosante idiopática da órbita: estudo clínico-patológico. Rev Bras Oftalmol. 2012 Set-Out; 71(5):292-5.

21. Laignier MR, Castro MA, Sá PSC. De olhos bem abertos: investigando acuidade visual dos alunos de uma escola municipal de Vitória. Esc Anna Nery. 2010 Jan-Mar; 14(1):113-9.

22. Lopes MSV, Saraiva KRO, Fernandes AFC, Ximenes LB. Análise do conceito de promoção da saúde. Texto Contexto Enferm. 2010 Jul-Set; 19(3):461-8.
23. Monteiro GBM, Temporini ER, Carvalho KM. Optical aids for low vision: use of the Internet to guide teachers of the visually impaired. Arq Bras Oftalmol. 2012 May-Jun; 75(3):166-9.

24. Ribeiro GB, Coelho ALD, Chaves PHP, Macedo RL, Silva TAB. Ophthalmologic screening of children of public schools in Belo Horizonte/MG: an overview about the visual impairment in children. Rev Bras Oftalmol. 2015 Oct; 74(5):288-91.

25. Penteado RZ, Ribas TM. Educative processes in the vocal health of teachers: a literature review of Brazilian studies in speech-language pathology and audiology. Rev Soc Bras Fonoaudiol. 2011 Apr-Jun; 16(2):233-9.

26. Carter MJ, Lansingh VC, Schacht G, Río del Amo M, Scalamogna M, France TD.Visual acuity and refraction by age for children of three different ethnic groups in Paraguay. Arq Bras Oftalmol. 2013 Jan; 76(2):94-7.

27. Comparato D. Da criação ao roteiro: teoria e prática. São Paulo: Summus; 2009.

28. Arruda FT, Danek A, Abrão KC, Quilici AP. Elaboração de vídeos médicos educacionais para treinamento de habilidades de estudantes do curso de medicina. Rev Bras Educ Med. 2012 Jul-Set; 36(3):431-5.

29. Moreira CB, Bernardo EBR, Catunda HLO, Aquino PS, Santos MCL, Fernandes AFC. Construção de um vídeo educativo sobre deteç̧ão precoce do câncer de mama. Rev Bras Cancerol. 2013 Jul-Set; 59(3):401-7.

30. Stina APN, Zamarioli CM, Carvalho EC. Effect of educational video on the student's knowledge about oral hygiene of patients undergoing chemotherapy. Esc Anna Nery. 2015 Apr-Jun; 19(2):220-5.

31. Ferreira MVF, Godoy S, Góes FSN, Rossini FP, Andrade D. Câmera e ação na execução do curativo do cateter venoso central. Rev Latino-Am Enfermagem. 2015 Nov-Dez; 23(6):1181-6. 